УДК 633.88:664.68

\title{
STUDY OF THE CONTENT OF BIOLOGICALLY ACTIVE COMPOUNDS IN MONARDA DIDYMA LEAVES WITH AIM OF THE USE OF SPISE-AROMATIC PHYTO RAW MATERIALS IN PRODUCTION OF CRACKERS WITH EXTENDED SHELF LIFE
}

\author{
V. Obolkina, T. Nosenko, O. Dzyhar \\ National University of Food Technologies \\ D. Rakhmetov \\ M.M. Hryshko National Botanical Garden
}

\begin{tabular}{|c|c|}
\hline Key words: & \multirow{11}{*}{$\begin{array}{l}\text { It was determined the content of biologically active com- } \\
\text { pounds in leaves of monarda didyma, it was identified the } \\
\text { composition of such components as phenolic and sub- } \\
\text { stances, terpenes, terpenoids, sugars and other substances. } \\
\text { The high antioxidant potential of raw materials is proven } \\
\text { due to the presence of phenolcarbonic acids, flavonoids and } \\
\text { also the bactericidal properties due to the content of thymol, } \\
\text { carvacrol, d-germacrene, } \alpha \text {-terpinolene. The efficiency of } \\
\text { the use of native spice-aromatic phyto raw materials as } \\
\text { natural antioxidant, preservation agent and flavoring in the } \\
\text { technologies of new food products, especially crackers with } \\
\text { spicy taste, is substantiated. }\end{array}$} \\
\hline Monarda didyma & \\
\hline Biologically active & \\
\hline compounds & \\
\hline Antioxidants & \\
\hline Aromatic compounds & \\
\hline Preservation agents & \\
\hline Spice-aromatic phyto raw & \\
\hline materials & \\
\hline Phenolic cor & \\
\hline $\begin{array}{r}\text { Articl } \\
\text { Received } 0 \\
\text { Received }\end{array}$ & \\
\hline
\end{tabular}

28.11.2017

Accepted 18.12.2017

Corresponding author:

O. Dzyhar

E-mail:

npnuht@ukr.net

DOI: $10.24263 / 2225-2924-2017-23-6-17$

\section{ВИВЧЕННЯ ВМІСТУ БІОЛОГІЧНО АКТИВНИХ СПОЛУК У ЛИСТІ МОНАРДИ ДВІЙЧАСТОЇ 3 МЕТОЮ ВИКОРИСТАННЯ ПРЯНО-АРОМАТИЧНОї ФІТОСИРОВИНИ ПРИ СТВОРЕННІ КРЕКЕРА \\ 3 ПОДОВЖЕНИМ ТЕРМІНОМ ПРИДАТНОСТІ}

В.І. Оболкіна, Т.Т. Носенко, О.О. Дзигар

Національний університет харчових технологій

Д.Б. Рахметов

Національний ботанічний сад імені М.М. Гришка НАН України

У статті визначено вміст біологічно активних сполук у листі монарди двійчастої, ідентифіковано склад фенольних, ароматичних сполук, терпенів, 
терпеноїдів, иукрів та інших речовин. Доведено високий антиоксидантний потениіал сировини завдяки наявності фенолкарбонових кислот, флавоноїдів $i$ бактерицидних властивостивостей завдяки вмісту тимолу, карвакролу, $d$-гермакрину, альфа-терпіноліну. Обтрунтовано ефективність використання вітчизняної пряно-ароматичної фітосировини у технологіях нових харчових продуктів, зокрема крекерів з пікантним смаком, як природного антиоксиданта, консерванта, ароматизатора.

Ключові слова: монарда двійчаста, біологічно активні речовини, антиоксиданти, ароматичні сполуки, консерванти, пряно-ароматична фітосировина, фенольні сполуки.

Постановка проблеми. Пряно-смакові рослини є перспективним джерелом для харчової галузі, зокрема кондитерської. Ефірні олії, цукри, дубильні та фенольні речовини відіграють важливу роль у забезпеченні смаку й аромату кондитерських виробів. Перспективною рослинною фітосировиною, що має приємний смак і аромат, підвищений вміст біологічно активних речовин, які виявляють позитивну дію на організм людини, зокрема антиоксидантну, протекторну, антисептичну, протизапальну, є листя монарди двійчастої.

Монарда двійчаста (Monarda didyma) - багаторічна трав'яниста рослина, що належить до родини Lamiaceae. Культивуються переважно такі види рослин: M. didyma, M. fistulosa, M. punctata та M. citriodora. Їх використовують у харчовій, ефіроолійній промисловості та медицині. Ефірна олія монарди має високу бактерицидну активність, яка зберігається при переробці сировини. У США M. punctata, M. fistulosa та M. didyma 31882 р. по 1950 р. входили у Фармакопею як джерело рослинного тимолу. Антисептик тимол широко використовують у медицині як фунгіцидний, бактерицидний та антигельмінтний засіб [1-6].

Якість продуктів, виготовлених 3 додаванням пряно-ароматичної сировини, залежить від таких смакоутворюючих речовин, як цукри, кислоти, дубильні речовини, флавоноїди тощо. Але перш за все пряно-ароматичні рослини цінують за вміст ефірної олій, яка надає фітомасі приємного аромату. Види роду Monarda давно користуються популярністю в Свропі як перспективні ефіроолійні рослини. Селекційні дослідження та вивчення компонентного складу ефірної олії рослин M. fistulosa та M. didyma проводилися в Росії, Молдові та Литві [7-11].

Листя монарди $є$ джерелом натуральних антиоксидантів, насамперед фенольних сполук, які здатні швидко реагувати з пероксидними радикалами, руйнувати гідропероксиди без утворення вільних радикалів, що спричиняє розривання ланцюга окисних реакцій і сповільнення швидкості окиснення жирів під час зберігання, подовжуючи такими чином термін придатності виробів [12; 13]. На відміну від країн Свропи та Америки, де монарда введена в культуру як пряно-ароматична та лікарська рослина, в Україні вона не набула значного поширення.

Фенольні сполуки, наявні у рослинах, рідко зустрічаються у вільному стані. Більшість їх представлено у вигляді різноманітних О- і С-глікозидів. 
Різноманіття флавоноїдних глікозидів обумовлено значним набором цукрів (глюкози, арабінози, ксилози та ін.) і можливостями приєднання їх як агліконів, а також тим, що цукри можуть мати різну конфігурацію глікозидних зв'язків. Отже, ідентифікаційне та кількісне визначення фенольних сполук у рослинній сировині потребує багатосторонніх досліджень. Тому для досліджень було використано комплекс методів, що доповнюють один одного. Найбільш доцільним є метод високоефективної рідинної хроматографії, який дає можливість визначити класи органічних сполук.

Метою дослідження $\epsilon$ вивчення хімічного складу та визначення вмісту біологічно активних сполук у листі монарди двійчастої і можливості застосування вітчизняної пряно-ароматичної фітосировини у виробництві нових борошняних кондитерських виробів, зокрема крекерів з пікантним смаком.

Об'єкти і методи. Об'єктом досліджень було листя монарди двійчастої (Monarda didyma), зразки отримували у Національному ботанічному саду ім. М.М. Гришка НАН України. Дослідження хімічного складу листя монарди двійчастої проводили у лабораторії НВК «Экофарм» методами:

- ультрашвидкісної високоефективної рідинної хроматографії (UPLC) при діодноматричному детектуванні (PDA), який одночасно записує електронний спектр поглинання сполук. Результати отримані на приладі фірми WATERS(USA). Аналіз проводили в градієнтному режимі зміни складу рухомої фази (ацетонитрил-вода). Колонка ACQUITY UPLC®BEHC 18 1,7 $\mu \mathrm{m}, 50 * 2,1 \mathrm{~mm}$;

- спектроскопії. Результати були отримані на приладі фірми Specord 210 Plus (Німеччина);

- газової хроматографії з мас-селективним детектуванням та бібліотекою мас-спектрів до і після кислотного гідролізу вихідних та модифікованих (TMS дериватів) форм. Результати були отримані на приладі фірми Agilent GC/MSD 7890A/5975C з капілярною колонкою HP-5MS.

Оскільки органічні сполуки, що містять рухливий атом водню (вуглеводи, кислоти, флавоноїди тощо), погано піддаються аналізу методом газової хроматографії, на практиці використовують метод заміщення протону на більш гідрофобну групу, що дає змогу застосувати метод газової хроматографії:

$$
\mathrm{R}^{\prime}-\mathrm{OH}\left(-\mathrm{NH}_{2} ;-\mathrm{NH}\right)+-\mathrm{Si}\left(\mathrm{CH}_{3}\right)_{3} \rightarrow \mathrm{R}^{\prime}-\mathrm{O}-\mathrm{Si}\left(\mathrm{CH}_{3}\right)_{3} \text {. }
$$

3 цією метою успішно використовують ангідриди, хлорангідриди, альдегіди, хлорвмісні сполуки. В результаті утворюється гідрофобна сполука, що покращує хроматографічні характеристики, селективність, а також робить достовірну ідентифікацію. Застосування мас-селективого детектора суттєво підвищує ефективність ідентифікаційного процесу (за наявності бібліотеки мас-спектрів). У зв'язку з тим, що сполуки з рухливими атомами водню в рослинах наявні у кон'югованому вигляді і такі форми складні для ідентифікації, для отримання вільних агліконів було використано кислотний гідроліз. Після проведення гідролізу, аглікони виділяли екстракційним методом. Також досліджували етанольні розчини гідролізатів після видалення у вакуумі розчинника (етилового спирту).

Для ідентифікації сполук з рухливими атомами використано метод дериватизації (отримання похідних), що дає змогу збільшувати молекулярну масу 
вихідної сполуки на відому величину, проводити більш якісне хроматографування, а також, збільшивши iї вихідну молекулярну масу, - достовірну ідентифікацію. В дослідженнях використовували для цієї мети реагент $\mathrm{N}$-метил-N-триметилсиліл-трифторацетамід (TMS).

Отримання етанольного конщентрату (органічних сполук). Наважку сухої подрібненої сировини (2,5 г) переносили у плоскодонну колбу об'ємом 100 мл, доливали 60 мл 96\% етилового спирту і приєднували до зворотного холодильнику та витримували на киплячій водяній бані протягом 90 хв. Після цього водяну баню охолоджували, холодильник промивали 5 мл етиловим спиртом і вміст колби переносили (відфільтровували) в мірну колбу об'ємом 100 мл. Потім у колбу додавали 35 мл етилового спирту і повторювали процедуру. Об'єм етанольного концентрату доводили до 100 мл.

Проведення кислотного гідролізу. Наважку сировини (приблизно 0,4 г), зваженої з точністю до четвертого знака, переносили у плоскодонну колбу об'ємом 100 мл, додавали 20 мл етилового спирту, 20 мл дистильованої води та 10 мл концентрованої соляної кислоти. Після приєднання колби до зворотного холодильника, суміш витримували 90 хв на киплячій водяній бані. Після цього холодильник промивали 20 мл дистильованої води, охолоджували колбу. Вміст колби переносили в ділильну воронку через паперовий фільтр об'ємом 100 мл, вносили 25 г хлориду натрію, ретельно перемішували i вилучали органічні сполуки етилацетатом (попередньо додавши до нього воду) - двічі по 30 мл. Після висушування етилацетатних екстрактів безводним сульфатом натрію, органічний розчинник відганяли у вакуумі. Залишок після відгонки розчиняли в 50 мл етилового спирту.

Отримання TMS дериватів. 5 мл етанольного концентрату зразка поміщали у віалу і при $78^{\circ} \mathrm{C}$ видаляли етиловий спирт. До сухого залишку доливали 300 мкг безводного піридину і 100 мкг реагенту N-метил-N-триметилсиліл-трифторацетамід. Віалу закривали і поміщали в УЗБ на 30 хв. Після цього у віалу додавали 1 мл ацетонітриту, перемішували і проводили дослідження методом ГX/MS згідно з описаною методикою.

Результати і обговорення. Розділення етанольного концентрату методом UPLC-PDA підтверджує наявність у них фенольних і поліфенольних сполук (рис. 1). Аналіз дав змогу ідентифікувати 8 сполук. Визначено кількісне співвідношення між цими сполуками (табл. 1).

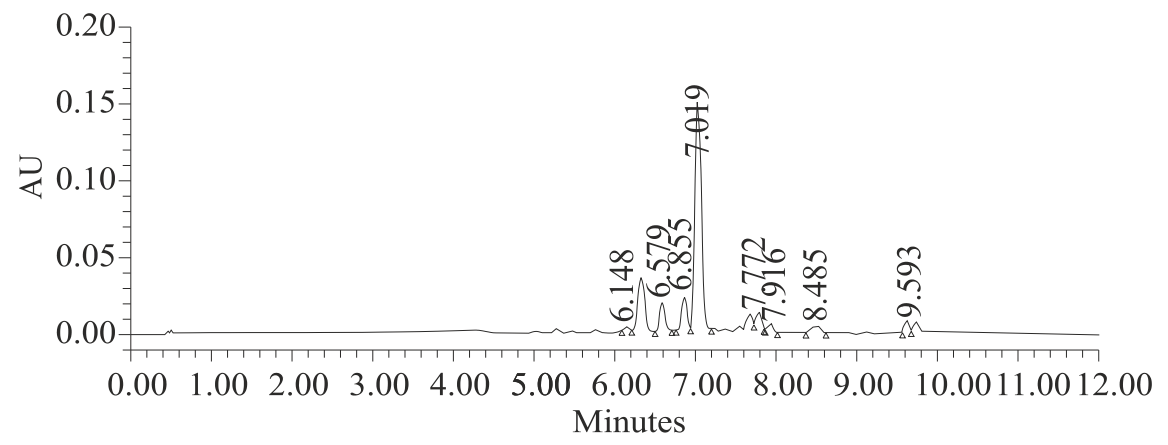

Рис. 1. Хроматограма вихідного етанольного концентрату (PDA $335.0 \mathrm{~nm}$ ) 
FOOD TECHNOLOGY

Таблиия 1. Кількісне співвідношення сполук (PDA 335.0 nm)

\begin{tabular}{|c|c|c|c|}
\hline № & Об’єм зразка & Тривалість утримання, хв & Масова частка від суми, \% \\
\hline 1 & 0,50 & 6,148 & 0,77 \\
\hline 2 & 0,50 & 6,579 & 7,58 \\
\hline 3 & 0,50 & 6,855 & 8,79 \\
\hline 4 & 0,50 & 7,019 & 72,82 \\
\hline 5 & 0,50 & 7,772 & 3,23 \\
\hline 6 & 0,50 & 7,916 & 1,87 \\
\hline 7 & 0,50 & 8,485 & 2,94 \\
\hline 8 & 0,50 & 9,593 & 2,00 \\
\hline
\end{tabular}

Після проведення кислотного гідролізу наважки сировини, тривалість утримання компонентів гідролізату відрізнялась від вихідного етанольного концентрату (рис. 2). На хроматограмі були ідентифіковані фенолкарбонові кислоти $(4,26 ; 8,81$ хв) та флавоноїди $(6,32 ; 7,65 ; 7,79$ і 8,49 хв). Визначено кількісне співвідношення компонентів гідролізату (табл. 2).

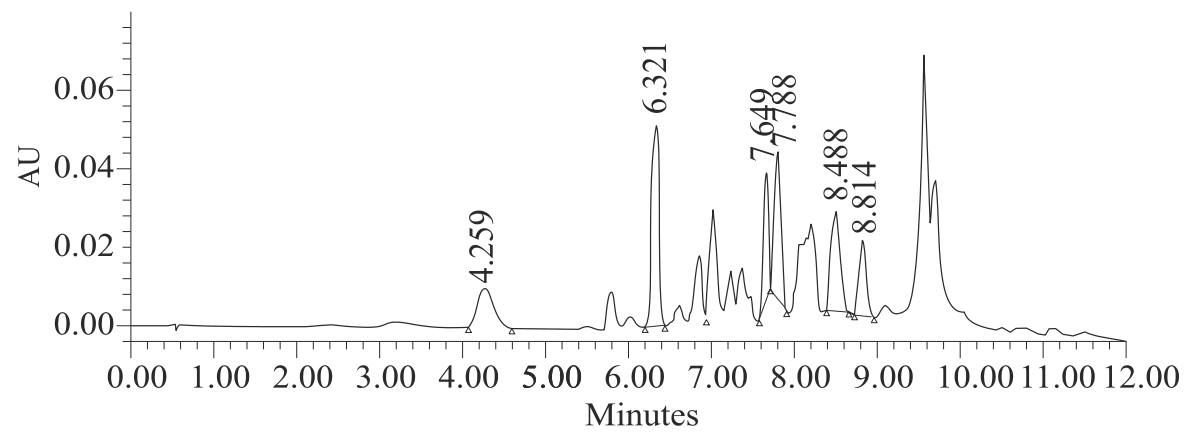

Рис. 2. Хроматограма кислотного гідролізату (PDA $350.0 \mathrm{~nm})$

Таблиия 2. Масова частка компонентів гідролізату (PDA $350.0 \mathrm{~nm}$ )

\begin{tabular}{|c|c|c|c|}
\hline № & Об’єм зразка & Тривалість утримання, хв & Масова частка від суми, \% \\
\hline 1 & 1,00 & 4,259 & 12,56 \\
\hline 2 & 1,00 & 6,321 & 25,71 \\
\hline 3 & 1,00 & 7,649 & 13,26 \\
\hline 4 & 1,00 & 7,788 & 19,49 \\
\hline 5 & 1,00 & 8,488 & 17,83 \\
\hline 6 & 1,00 & 8,814 & 11,14 \\
\hline
\end{tabular}

Абсорбція

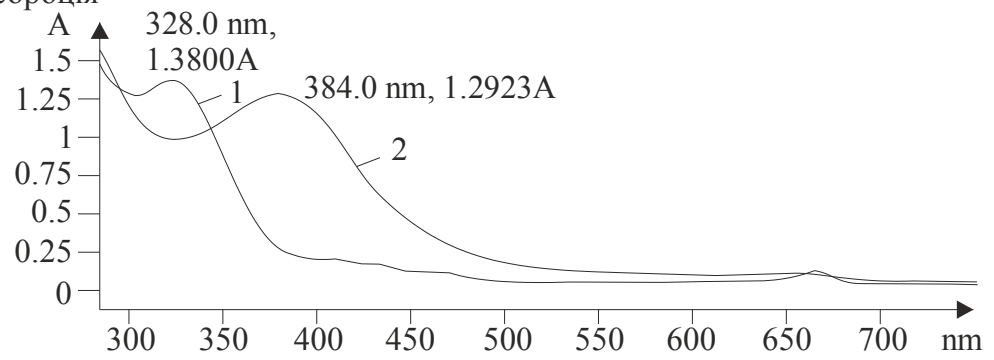

Рис. 3. Спектри поглинання вихідного етанольного концентрату

$$
(1-\mathrm{pH}=6,5 ; 2-\mathrm{pH}=11,8)
$$


Аналіз спектрів (рис. 3) поглинання етанольного концентрату свідчить про наявність у ньому великої кількості сполук, що містять рухливий атом водню. Збільшення $\mathrm{pH}$ розчину (крива 2) обумовлює значне зміщення максимуму поглинання з 328 до $384 \mathrm{~nm}$.

Після кислотного гідролізу в спектрах поглинання також відбувалося зміщення максимуму (рис. 4). Однак, на відміну від вихідного зразка, в даному випадку відсутня точка перетину кривих, що вказує на руйнування деяких сполук при підвищенні $\mathrm{pH}$ розчину.

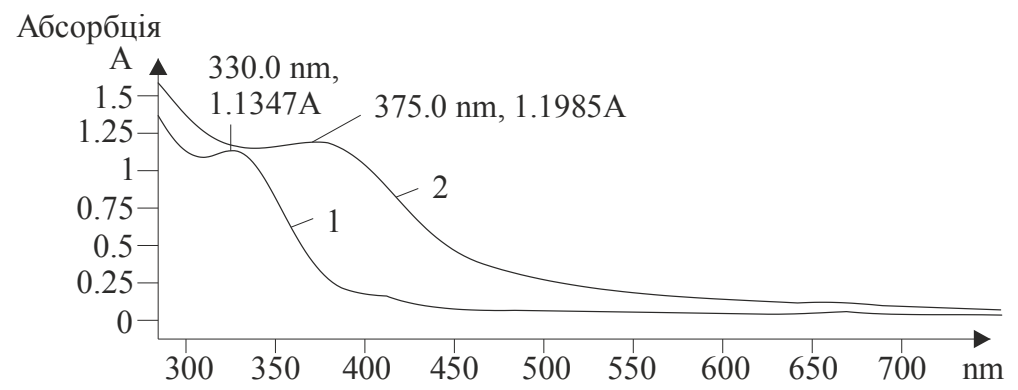

Рис. 4. Спектри поглинання кислотного гідролізату $(1-\mathrm{pH}=6,5 ; 2-\mathrm{pH}=11,8)$

Аналіз результатів мас-хроматограми вихідного зразка дав змогу ідентифікувати такі сполуки (рис. 5): альфа-туйон, вініламілкарбінол, о-кумол, альфа-терпінолін, метиловий ефір тиміну, карвакрол, тимол, d-гермакрин, амідолеїнова кислота, третбутилкатехол.

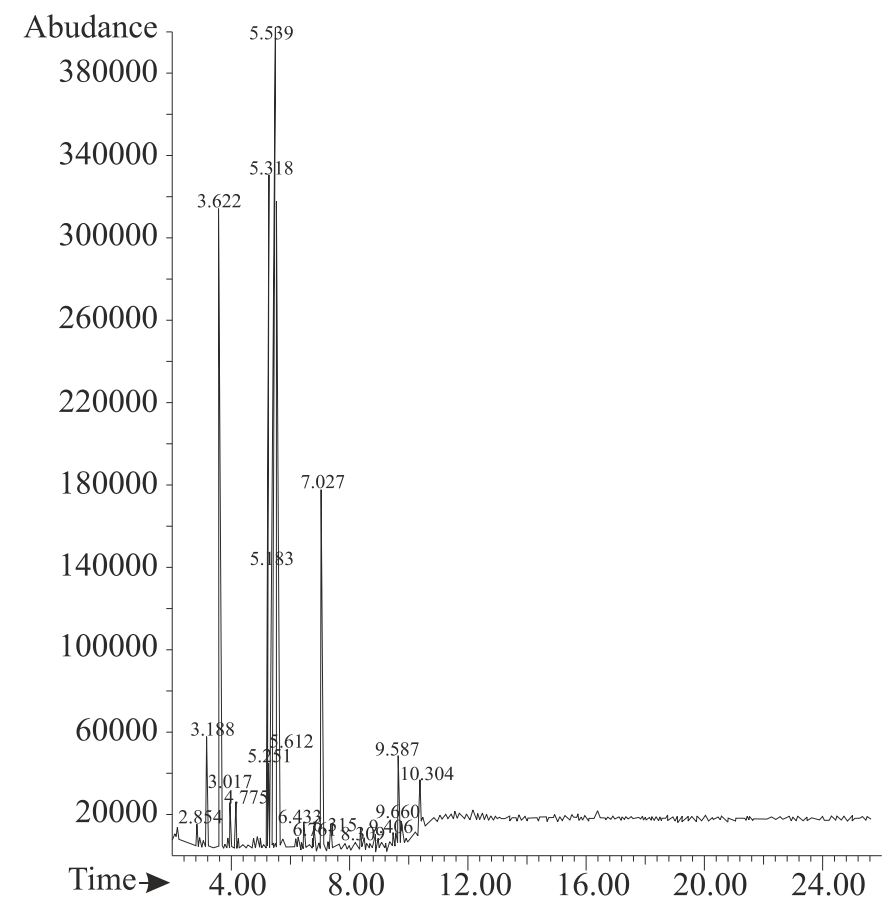

Рис. 5. Мас-хроматограма вихідного етанольного концентрату 
Після кислотного гідролізу низка летких сполук не була виявлена (рис. 6), але з'явилися сполуки, які були зв'язані гідроксилвмісними сполуками (флавоноїди, фенолкарбонові кислоти), насамперед етиловий ефір левулінової кислоти, етилпальмітат, тимол (табл. 3).

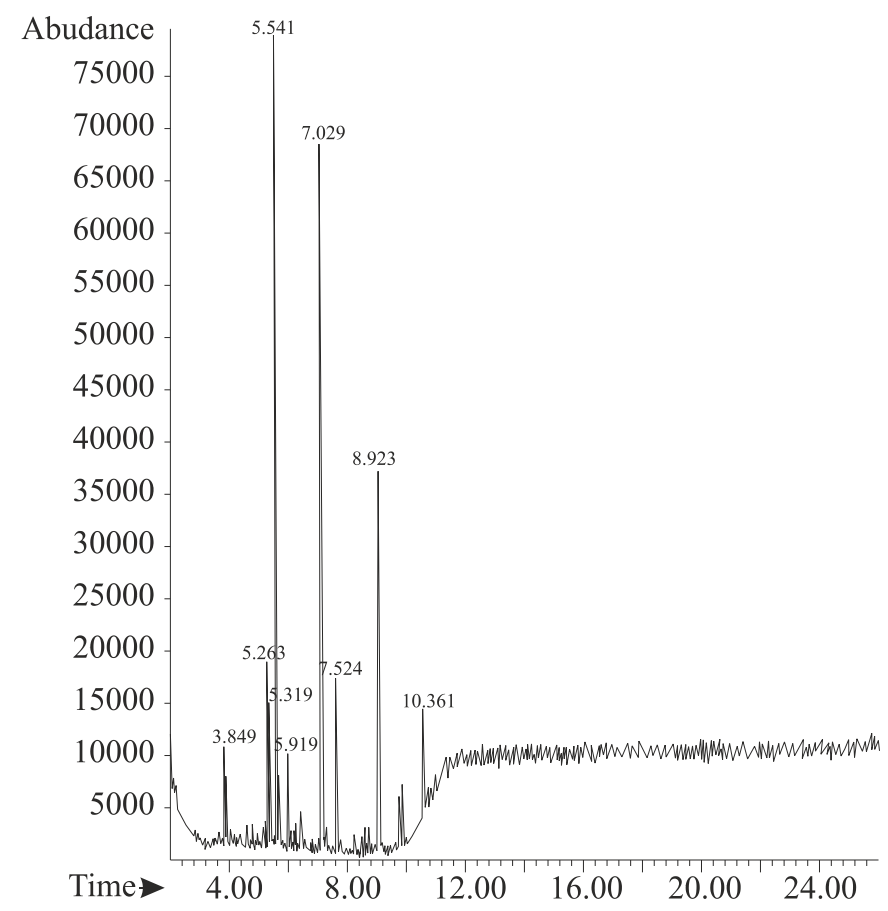

Рис. 6. Мас-хроматограма кислотного гідролізату

Таблиия 3. Сполуки, виявлені в екстракті листя монарди методом мас-хроматографії

\begin{tabular}{|c|c|c|c|c|}
\hline № & $\begin{array}{c}\text { Назва } \\
\text { сполуки }\end{array}$ & $\begin{array}{c}\text { Хімічна } \\
\text { формула }\end{array}$ & Структурна формула & Властивості \\
\hline 1 & 2 & 3 & & 5 \\
\hline 1 & Альфа-туйон & $\mathrm{C}_{10} \mathrm{H}_{16} \mathrm{O}$ & & $\begin{array}{c}\text { Ароматична речовина, 3 } \\
\text { характерним запахом, } \\
\text { що нагадує ментол. } \\
\text { однією із двох } \\
\text { стереоізомерних форм } \\
\text { туйону. }\end{array}$ \\
\hline 2 & о-кумол & $\mathrm{C}_{6} \mathrm{H}_{5} \mathrm{CH}\left(\mathrm{CH}_{3}\right)_{2}$ & & $\begin{array}{c}\text { Органічна сполука ряду } \\
\text { ароматичних } \\
\text { вуглеводнів. }\end{array}$ \\
\hline
\end{tabular}


Продовження табл. 3.

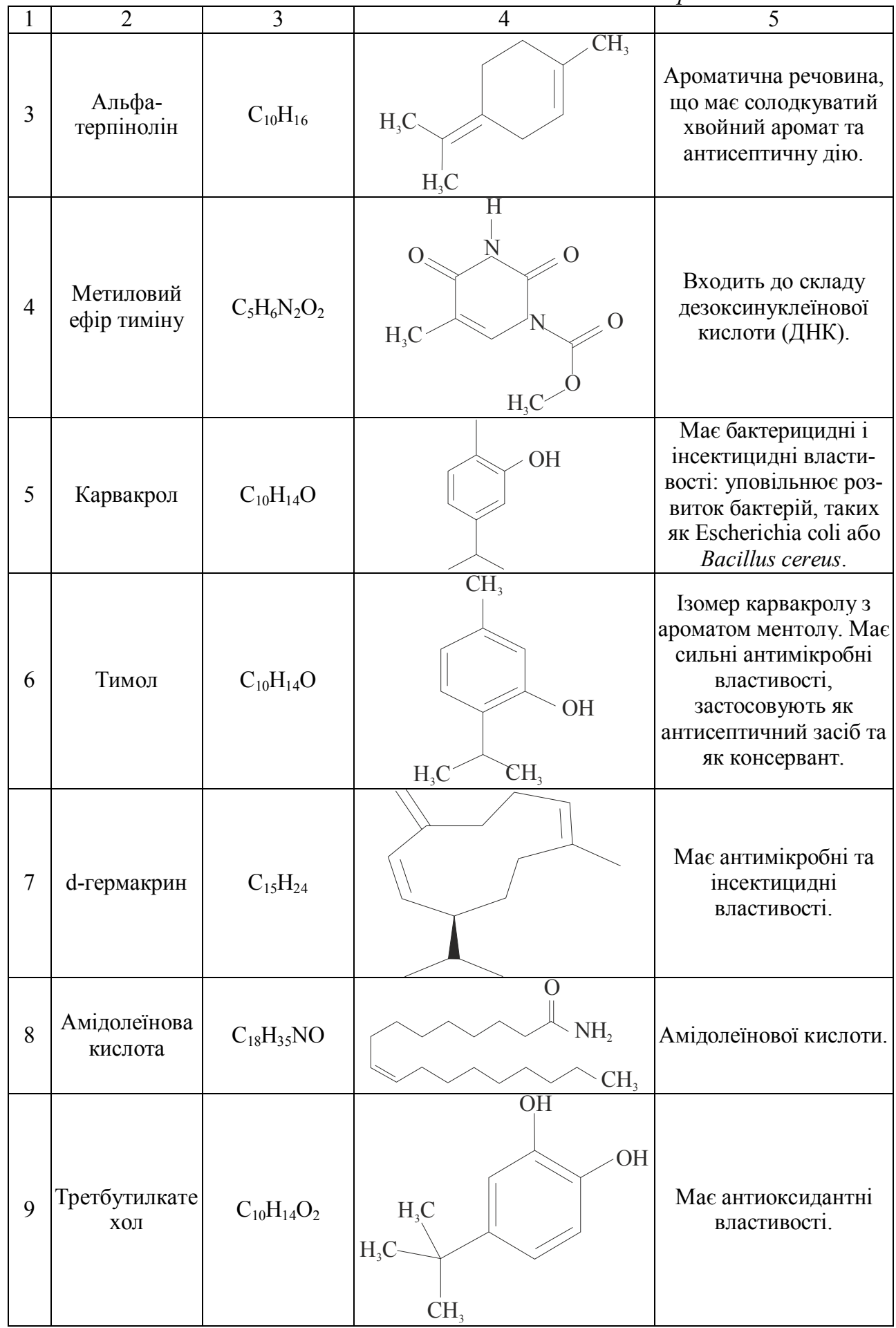




\begin{tabular}{|c|c|c|c|c|}
\hline & & & & Закінчення табл. 3. \\
\hline 10 & $\begin{array}{c}\text { Етиловий ефір } \\
\text { левулінової } \\
\text { кислоти }\end{array}$ & $\mathrm{C}_{7} \mathrm{H}_{13} \mathrm{O}_{3}$ & $\mathrm{O}$ & $\begin{array}{c}\text { Ефір левулінової } \\
\text { кислоти, } \epsilon \\
\text { консервантом, має } \\
\text { антисептичні } \\
\text { властивості. }\end{array}$ \\
\hline 11 & Етилпальмітат & $\mathrm{C}_{18} \mathrm{H}_{36} \mathrm{O}_{2}$ & $m_{\mathrm{O} \wedge}^{\mathrm{O}}$ & $\begin{array}{c}\text { Етиловий ефір } \\
\text { пальмітинової кислоти. }\end{array}$ \\
\hline
\end{tabular}

Кількість ідентифікованих сполук суттєво зросла після TMS дериватизації (рис. 7). Після TMS дериватизації встановили наявність у зразку бетагідроксимасляної кислоти, гліцерину, еритритолу, 1-проліну, третбутилгідрохінону, ксилітолу, арабітолу. Виявлено значну кількість вуглеводів: арабінофуранозу, фруктозу, d-глюкозу, цукрозу, d-манітол, альфа-1-галактофуранозу, арабінозу. Знайдено фенолкарбонову кислоту (кавову), а також низку жирних кислот: пальмітинову, альфа-ліноленову, стеаринову, ейкозанову, лауринову.

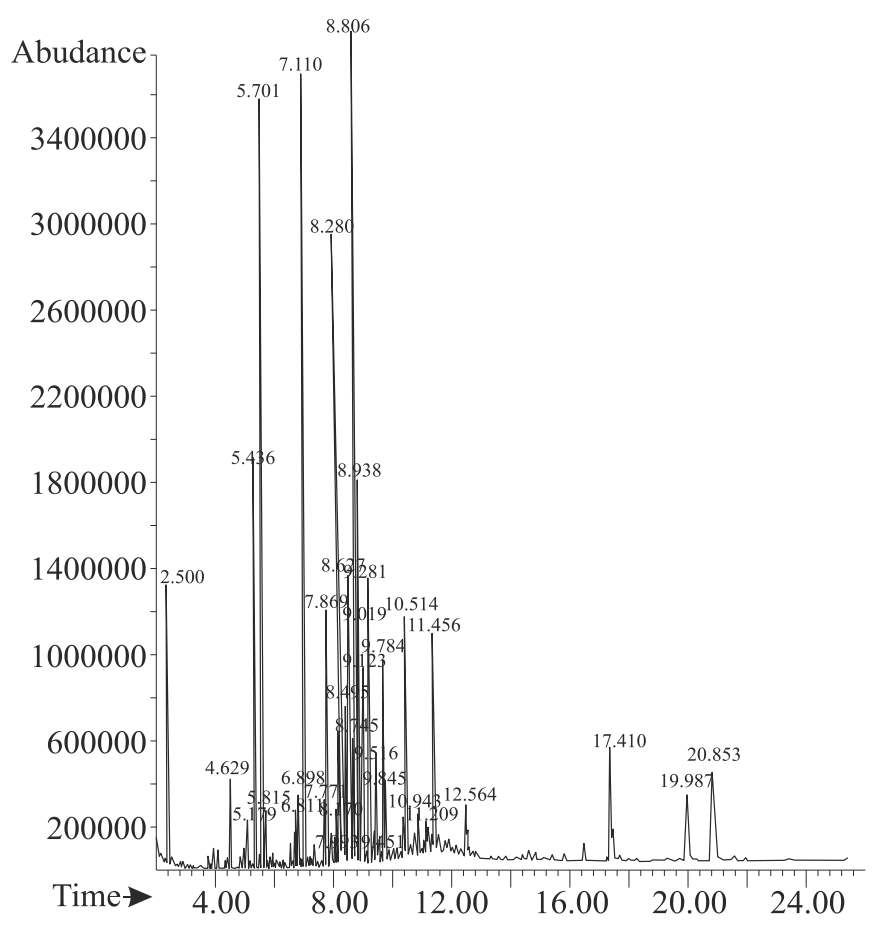

Рис. 7. Мас-хроматограма TMS дериватів вихідного етанольного концентрату

У складі TMS дериватів після кислотного гідролізу (рис. 8) ідентифіковано: бета-гідроксимасляну кислоту, метиловий ефір орнітину, тимол, третбутилгідрохінон, етиловий ефір лимонної кислоти, 3-(3,4-дигідроксифеніл) лактонову кислоту, ефір катехоллактату, кавову кислоту. Третбутилгідрохінон застосовується як антиокислювач, належить до групи фенольних антиоксидантів, зупиняє процес окислення на ранніх стадіях. Кавова кислота $є$ 
ненасиченою карбоновою кислотою, яка має імуномодулюючу, протизапальну та антиоксидантну активність.

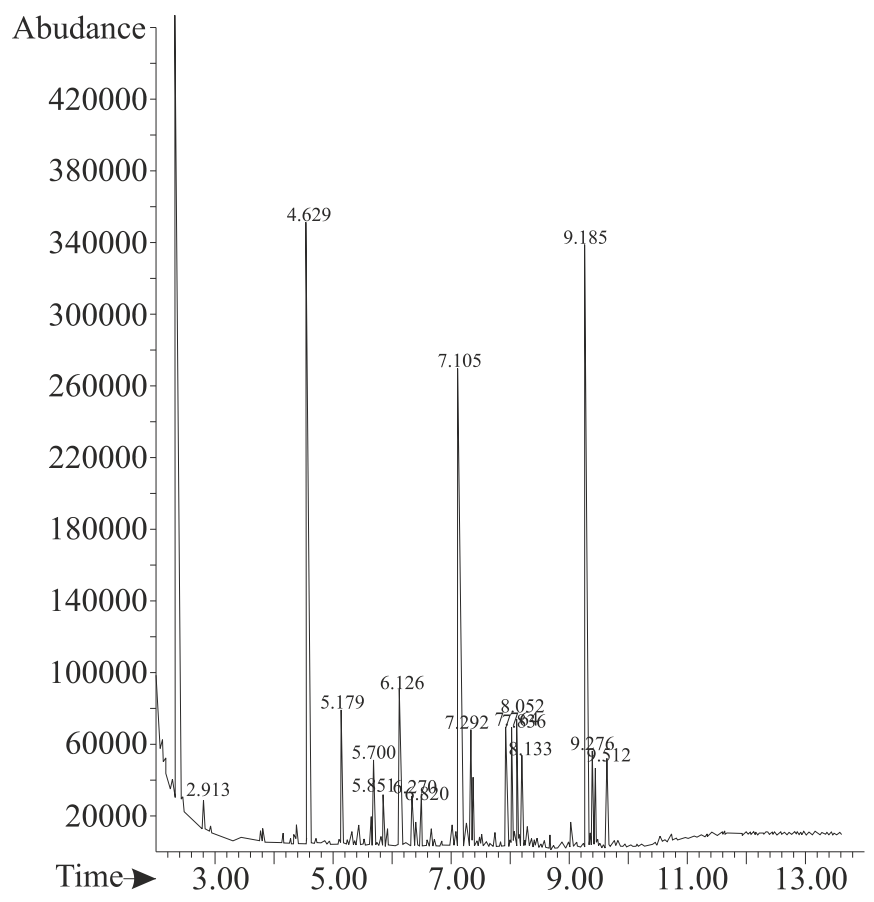

Рис. 8. Мас-хроматограма TMS дериватів кислотного гідролізату

\section{Висновки}

У результаті досліджень хімічного складу фенольних сполук, які містяться у листі монарди двійчастої (Monarda didyma), методами ультрашвидкісної високоефективної рідинної хроматографії, спектроскопії, газової хроматографії з мас-селективним детектуванням ідентифіковані фенольні сполуки, проаналізований їх хімічний склад.

Доведено високий антиоксидантний потенціал сировини завдяки наявності фенолкарбонових кислот, зокрема кавової, флавоноїдів, третбутилкатехолу, третбутилгідрохінону та іiі потенційні бактерицидні властивості завдяки вмісту тимолу, карвакролу, d-гермакрину, альфа-терпіноліну. Встановлено склад ароматичних речовин та інших складових монарди двійчастої.

За результатами досліджень рекомендовано використання пряно-ароматичної рослинної сировини у технологіях борошняних кондитерських виробів як ефективного природного антиоксиданта, консерванта, ароматизатора.

\section{Література}

1. Кораблева О.А. Монарда в декоративном садоводстве / О.А. Кораблева, М.В. Рысь // Биологический вестник. - Харьков. - 2006. - Т. 10. —№ 2. - С. $6-8$.

2. Свиденко Л. Інтродукція Monarda fistulosa L. в Херсонській області / Л. Свиденко // Вісник Львів. ун-ту. — 2004. — № 36. — С. 319-324. 
3. Работягов В.Д. Интродукция и селекция эфирномасличных растений в Никитском ботаническом саду / В.Д. Работягов, Л.А. Хлыпенко, В.И. Машанов и др. // Бюлетень ГБС. - Москва : Наука. - 2003. - Вып. 186. - С. 10-14.

4. Mazza G. Monarda: A source of geraniol, linalool, thymol and carvacrol-rich essential oils / G. Mazza, F. Kiehn, H. Marshall // In: J.Janick and J.Simon (eds.), New crops. Wiley. - New York. - 1993. - P. 628-631.

5. Singhurst J.R. Monarda luteola (Lamiaceae): a new species from Northeast Texas and Southwest Arkansas / J.R. Singhurst // Phytoneuron. - 2011. - № 41. - C. 1-5.

6. Floden A. A new beebalm Monarda austroappalachiana (Lamiaceae L.) from the Southern Appalachians / A. Floden // Phytoneuron. - 2015. - \# 28. - C. 3-12.

7. Савиикене H. Monarda didyma - лекарственное и декоративное растение. Актуальные проблемы инноваций с нетрадиционными растительными ресурсами и создания функциональных продуктов / Н. Савицкене // Матер. 1-й Российской научно-прак. конф. Москва, 2001. - С. 249-250.

8. Корчашкина H.B. Содержание эфирного масла в сырье Monarda didyma L., Monarda fistulosa L. и Monarda media L. в условиях Московской области / Н.В. Корчашкина, Е.Л. Маланкина // Матер. междунар. научно-прак. конф. посвященной 10-летию образования Ботанического сада Белгородского государственного университета. «Ботанические сады в 21 веке: сохранение биоразнообразия, стратегия развития и инновационные решения». Белгород. - 2009. - С. 443- 444.

9. Перспективы выращивания монарды лимонной в качестве лекарственного и эфирномасличного растения в условиях Московской области / Е.Л. Маланкина, Н.В. Корчашкина, А.А. Терехин и др. // Нетрадиционные природные ресурсы, инновационные технологии и продукты переработки нетрадиционных культур. Сборник научных трудов. - Москва, 2003. - Вып. 7. - С. 233-238.

10. Рысь M.B. Морфологическая характеристика новых сортообразцов монарды / М.В. Рись // Матер. симпозиума «Новые и нетрадиционные растения и перспективы их использования». - Москва, 2007. - С. 249-251.

11. Flavonoidų analizè raudonosios monardos (Monarda didyma L.) žieduose ir lapuose / Savickienè N., Dagilyte A., Barsteigienė Z. ir kt. // MEDICINA. — 2002. — T. 38. — \#. 11. P. $1119-1122$.

12. Zhan-guo L. Chemical Composition of Antibacterial Activity of Essential Oil from Monarda citriodora Flowers / L. Zhan-guo, L. Xiu-hui, L. Wei // Advanced Materials Research. 2011. - Vol. 183-185. - P. 920-924.

13. Bioassay-Guided Investigation of Two Monarda Essential Oils as Repellents of Yellow Fever Mosquito Aedes aegypti / Tabanca N., Bernier U., Ali A. et al. // Agricultural and Food chemistry. — 2013. — \# 61. - P. 8573 - 8580. 